\title{
RESISTENSI TOKOH-TOKOH PEREMPUAN TERHADAP PATRIARKI DALAM NOVEL GARIS PEREMPUAN KARYA SANIE B. KUNCORO
}

Resistence of Women Characters to Patriarchy in Novel Garis Perempuan by Sanie B. Kuncoro

\author{
Delmarrich Bilga Ayu Permatasari \\ Universitas Airlangga \\ pos-el: delmarrich_ayu@yahoo.com
}

\section{Naskah Diterima 5 September 2017 -Direvisi Akhir 29 November 2017 - Disetujui 29 November 2017 doi.org/10.26499/jentera.v6i2.439}

\begin{abstract}
Abstrak: Artikel ini bertujuan untuk mengungkap pemaknaan atas gerakan perlawanan atau resistensi tokoh-tokoh perempuan dalam novel Garis Perempuan karya Sanie B. Kuncoro. Tokoh Ranting, Gendhing, Tawangsri, dan Zhang Mey merupakan perempuan dewasa yang hidup di tengah arus modernitas namun memiliki akar budaya yang tidak dapat dilepaskan dari hukum patriarki yang kental. Dibesarkan dengan latar budaya yang berbeda-beda, keempat tokoh tersebut memiliki cara-cara tersendiri dalam meraih kesejahteraan, kebebasan pribadi, dan keadilan sosial yang secara keseluruhan diwujudkan dalam upaya pemaknaan terhadap virginitas. Dengan menggunakan konsep kritik sastra feminis dapat disimpulkan bahwa virginitas adalah sesuatu yang bersifat cair yang digunakan oleh perempuan sebagai bentuk penghargaan atas tubuhnya. Dengan mengapresiasi virginitasnya seorang perempuan telah berkuasa terhadap kepemilikan tubuhnya yang dalam budaya dan hukum patriarki kuasa perempuan atas kepemilikan tubuhnya seringkali tidak diindahkan.
\end{abstract}

Keywords: Perlawanan Perempuan, Poskolonialisme, virginitas, Sanie B. Kuncoro.

Abstract: This article aims to reveal the meaning of the resistance movement of female characters in the novel Garis Perempuan by Sanie B. Kuncoro. Ranting, Gendhing, Tawangsri and Zhang Mey are adult women who live in the midst of modernity, but have cultural roots that can not be separated from the thick patriarchal law. Raised with different cultural backgrounds, the four characters have their own way of making efforts to reach welfare, personal freedom, and social justice that are embodied as a whole in the effort to meaning the virginity. By using the concept of criticsm of feminies literature, it can be concluded that virginity is a liquid thing that women use as a form of appreciation of their bodies so that by apreciate its virginity a woman has power over her body ownership which in culture and patriarchy law women's authority over the possessions of their bodies is often ignored.

Keywords: Women's Resistance, Postcolonialism, virginity, Sanie B. Kuncoro.

How to cite: Permatasari, Delmarich Bilga Ayu. (2017). Resistensi Tokoh-tokoh Perempuan Terhadap Patriarki dalam Novel Garis Perempuan karya Sanie B Kuncoro. Jentera: Jurnal Kajian Sastra, 6 (2), 94-108. (https:/ / doi.org/10.26499/jentera.v6i2.439) 


\section{Pendahuluan}

Di tengah arus kehidupan yang tak pernah lepas dari wacana kolonialisme, praktik kuasa atas gender merupakan topik yang tak pernah sepi dibicarakan. Hal ini terlihat pula pada karya sastra. Pembahasan permasalahan kesetaraan gender dalam masyarakat lokal telah banyak dilakukan oleh sastrawan perempuan. Di Indonesia, persoalan gender yang mengedepankan aspek feminisme terdapat pada karya-karya Ayu Utami, antara lain: Saman (1998), Larung (2001), Bilangan Fu (2008), Djenar Maesa Ayu: Mereka Bilang, Saya Monyet (2002), Nayla (2005), 1 Perempuan 14 Lakilaki (2011), Laksmi Pamuntjak: Amba (2012), Aruna dan Lidahnya (2014), dan Leila S. Chudori: Malam Terakhir (1989), 9 Dari Nadira (2009), Pulang (2013).

Nenden (2012: 114), seorang akademisi sastra mengatakan bahwa meskipun feminisme berasal dari Barat, namun kondisi penindasan atas perempuan tidak hanya terdapat di Barat, tetapi juga terjadi dalam lingkup lokal. Artinya, kesadaran mengenai kesetaraan tidak hanya milik Barat, tetapi juga milik masyarakat yang ada di Timur. Oleh karena itu, pendiskriminasian laki-laki terhadap perempuan tersebut banyak tercermin dalam karya-karya sastra Indonesia. Hal tersebut sejalan dengan peran karya sastra yang pada hakikatnya merupakan usaha untuk menceritakan sebuah peristiwa, benda, apa pun, atau dengan kata lain untuk mengonstruksi realitas.

Dari sekian banyak karya sastra yang mengangkat tema feminisme, novel Garis Perempuan karya Sanie B. Kuncoro memiliki keunikan dalam hal pengangkatan tema perempuan dengan penekanan pada virginitas di keempat tokoh sentralnya. Virginitas dalam novel ini dianggap sebagai usaha untuk meresistensi diri terhadap hukum patriarki di Indonesia.

Garis Perempuan terdiri dari empat tokoh sentral yakni Gendhing, Ranting, Tawangsri, dan Zhang Mey. Keempat tokoh tersebut berlatar dari keluarga dan budaya patriarki yang menganggap virginitas sebagai hal yang suci dan sakral. Meski demikian, masing-masing tokoh memiliki pemaknaan tersendiri terhadap virginitas yang tidak selalu sejalan dengan makna virginitas yang dikonstruksikan budaya patriarki. Para tokoh perempuan mencoba mendobrak tirani patriarkis secara ideologis yang oleh Astutiningsih (2013:55) disebut sebagai upaya untuk melampaui sekat-sekat normatif di dunia yang patriarkal dan heteronormatif. Namun, meskipun para tokoh perempuan memiliki caranya sendiri dalam meresistensi budaya patriarki, teks diakhiri dengan nasib tokoh yang tetap hidup dalam norma, nilai, dan budaya patriarki yang sesuai dengan judul novel, Garis Perempuan.

Pada dasarnya novel Garis Perempuan menghadirkan topik feminis dengan cara yang ironi. Ironi menurut Ratna (2009:447) merupakan sindiran halus dengan menyembunyikan fakta yang sebenarnya dan mengungkapkan kebalikan dari fakta. Tokoh-tokoh perempuan memiliki sifat yang lemah lembut, sabar, dan penyayang sehingga tampak menderita dalam segala problematika yang menerpa hidupnya. Tokoh-tokoh perempuan dalam teks ini lahir dengan latar budaya patriarki yang kuat (Jawa dan Cina) sehingga tumbuh sebagai perempuan yang sesuai dengan citra yang dikondisikan budaya patriarki. Hidup sebagai perempuan yang terkonstruksikan sedemikian rupa, mengharuskan para 
tokohnya memilih jalan yang sesuai dengan tuntutan budaya.

Diceritakan bahwa tokoh Ranting, Gendhing, Tawangsri, dan Zhang Mey merupakan sekawan sahabat yang karib semenjak kecil. Ranting, si yatim yang lahir dari keluarga tak berkecukupan yang hidup menderita dalam arus kemiskinan. Gendhing adalah putri buruh cuci dan tukang becak yang selalu menemui hambatan ekonomi. Tawangsri adalah perempuan berpendidikan yang jatuh hati pada lelaki beristri. Zhang Mey, keturunan congkouren (Cina) yang harus hidup berbaur dengan warga pribumi. Keempat perempuan tersebut memiliki caranya sendiri dalam menjalani takdirnya sebagai perempuan Indonesia.

Cara keempat tokoh Garis Perempuan dalam meresistensi diri dari hukum patriarki penting untuk diteliti karena menandai praktik perempuan Indonesia untuk dapat meraih kesejahteraan, kebebasan pribadi, dan keadilan sosial di Indonesia. Patriarki sendiri tidak dapat dilepaskan dari praktik wacana kuasa. Terdapat keterbelahan kuasa yang tidak dapat dilepaskan dari hubungan oposisi biner laki-laki dan perempuan. Karena berkaitan erat dengan wacana kuasa, maka Garis Perempuan tepat apabila dianalisis dengan teori kritik sastra feminis yang merupakan sub keilmuan dari studi poskolonial.

Sejalan dengan penjabaran pada pendahuluan, penelitian ini bertujuan untuk mengungkapkan cara tokohtokoh perempuan dalam meresistensi diri terhadap hukum patriarki di Indonesia dalam novel Garis Perempuan karya Sanie B. Kuncoro serta memaknainya. Penelitian ini dapat dilakukan dengan memanfaatkan konsep analisis kritik sastra feminis yang menekankan pada problematika kuasa dan seksualitas yang terdapat pada teks Garis Perempuan.

Sebelumnya perlu diketahui bahwa Sanie B Kuncoro merupakan penulis fiksi baik novel maupun cerpen yang karya-karyanya telah banyak diterbitkan dalam bentuk buku ataupun dimuat di media massa. Selain Garis Perempuan, novel-novelnya yang telah diterbitkan antara lain berjudul Kekasih Gelap (2008), Ma Yan (2009), Memilikimu (2011), Melepas Ranting Hati (2011), dan Sayap Cahaya (2011). Di samping novel, Kuncoro juga aktif dalam menulis cerpen yang dimuat di media massa maupun tergabung dalam antologi bersama. Beberapa cerpennya yang tergabung dalam antologi bersama antara lain: 24 Sauh (2009), Mimpi Bayang Jinga (2009), Silang Hati (2012), Alixitimia (2012), Dongeng Patah Hati (2013), dan Seribu Taun Mencintaimu (2017). Semenjak tahun 1981, Kuncoro telah memenangkan sejumlah lomba mengarang yang diadakan majalah Hai, Anita, Gadis, Femina, dan Tabloid Nyata. Hingga saat ini, cerpen-cerpennya seringkali dimuat di koran Kompas dan beberapa cerpennya juga masuk dalam buku antologi Kumpulan Cerpen Terbaik Kompas. Lulusan FISIP Universitas Diponegoro tahun 1987 ini mendapatkan predikat sebagai penulis yang kerap mengangkat tema sosial sebagai kritik atas kehidupan masyarakat Indonesia khususnya masyarakat Jawa yang sesuai dengan latar budayanya sebagai orang Jawa (Kusumawati, 2014).

Secara umum, karya-karya Kuncoro mengangkat tema besar ketidakadilan atau ketimpangan sosial yang sesuai dengan konsep poskolonialisme yang pada dasarnya karakter karya sastra poskolonialisme dapat 
dilihat dari hal implisit yang membangunnya. Bill Ashcroft, dkk (2003: xxiii) berpendapat bahwa kesusastraankesusastraan tersebut memiliki banyak persamaan satu sama lainnya; pertama, dalam bentuk paling mutakhirnya, mereka terlahir dari pengalaman kolonisasi; dan kedua, pernyataanpernyataannya mengungkapkan ketegangan-ketegangan yang mereka alami berkaitan dengan hadirnya kekuatan imperial, dan sekaligus menekankan perbedaannya dengan asumsi-asumsi yang dibangun oleh pusat imperial. Berkaitan dengan teori yang akan diterapkan, pemahaman terhadap kritik sastra feminis menjadi perlu. Kritik sastra feminis adalah sebuah cara dalam memandang karya sastra dengan meminjam gerakan feminis. Sebelum bergerak ke pemahaman menyeluruh terhadap kritik sastra feminis, ada baiknya mengetahui poskolonialisme sebagai bentuk dasar pemikiran analisis kritik sastra feminis.

Poskolonialisme pada dasarnya memiliki konsep dasar yang terkait dengan ranah pendidikan. Andreotti dalam Suwondo (2014: 96) menyimpulkan bahwa terdapat tiga nilai penting studi poskolonial terhadap pendidikan, yaitu: pertama, studi poskolonial dapat menjadi landasan dalam pengubahan kurikulum pendidikan; kedua, studi poskolonial dapat berkontribusi bagi penyadaran akan nilai tanggung jawab sosial, kesetaraan gender, sarana penegakan demokrasi, dan kemiskinan; ketiga, studi poskolonial mampu mengarahkan pendidikan ke pengembangan kepribadian dan penghargaan atas hak asasi manusia. Berkaitan dengan pemahaman tersebut, kajian poskolonialisme juga tidak dapat dilepaskan kaitannya terhadap novel sebagai bacaan pembentuk nilai dan karakter bangsa.

Gerakan feminis berakar dari penindasan kelas di dalam masyarakat, yaitu kelas laki-laki terhadap perempuan. Menurut Tan, (1996:13) ada beberapa hambatan mendasar yang menghalangi perempuan untuk berada pada barisan depan. Hambatan tersebut antara lain adalah hambatan fisik, teologis, sosial budaya, sikap pandang, dan historis. Selain itu, perempuan dianggap memiliki watak penuh kasih sayang (affective), empati (emphatic), dan perawat serta pengurus (nurturant) yang memaksa perempuan untuk harus selalu hidup dalam tatanan kodratnya. Ciri watak yang dimiliki perempuan ini tidaklah terlahir murni melainkan bentukkan dari masyarakat patriarkal. Beberapa hambatan yang dimiliki oleh perempuan menghambat perkembangan perempuan untuk menjadi manusia seutuhnya.

Pendapat lain mengemukakan bahwa aspek agama yang mendasari lahirnya gerakan feminisme. Agamaagama besar (Islam, Kristen, Yahudi) menempatkan kaum perempuan pada posisi yang lebih rendah daripada lakilaki. Ketika bersembahyang, kaum Yahudi kuno selalu mengucapkan terima kasih kepada Tuhan karena tidak dilahirkan sebagai perempuan. Agama Islam secara tegas menempatkan perempuan pada posisi yang menekankan pada fungsi reproduktivitas. "Perempuan, sejalan dengan fungsi reproduktif yang dimilikinya, mempunyai tugas mengandung anak (alhamalah), melahirkan (al-wiladah), menyusui (al-radla'ah), mengasuhnya (tarbiyah al-athfal), dan beberapa hal lain yang berkaitan." (Jamhari dan Ismatu Ropi, 2003: 146). Melalui pendapat tersebut tampak jelas terlihat bahwa 
agama pada dasarnya memiliki pandangan patriarkis yang menempatkan perempuan pada posisi marginal. Sejalan dengan pemaparan tersebut, Guamarwati (2009) menjelaskan bahwa konsep patriarki yang tumbuh subur dalam naungan ajaran agama berdampak pada sistem sosial patriarkis yang menjadi akar timbulnya berbagai kekerasan baik fisik maupun psikis yang dialamatkan oleh kaum laki-laki kepada perempuan.

Diskriminasi yang dilakukan laki-laki terhadap perempuan sesuai dengan pemahaman studi poskolonialisme. Poskolonialisme pada dasarnya mengkaji tentang bagaimana sesuatu mampu mengungkapkan jejak kolonialisme dalam segala bentuk konfrontasi yang terjadi dalam lingkup hubungan kekuasaan yang tidak setara. Wacananya meliputi jender, resistensi, penggugatan, yang pada dasarnya merupakan penolakan terhadap segala jenis penindasan. Garis Perempuan menyuarakan problem poskolonial karena mengandung relasi kuasa yang terdapat dalam praktik gender, yaitu wacana feminisme-maskulinisme atau konfrontasi yang terjadi atas laki-laki dan perempuan yang secara metode dapat dianalisis menggunakan teori kritik sastra feminis.

\section{Teori Kritik Sastra Feminis}

Selama ini telah terdapat perspektif umum yang menganggap bahwa yang mewakili pembaca, pencipta, dan kritikus karya sastra Barat adalah kaum laki-laki. Peran perempuan sebagai pengarang dan pembaca dikesampingkan sehingga kritik sastra feminis muncul untuk membawa persepsi dan harapan ke dalam dunia sastra. Batasan umum kritik sastra feminis yang diungkapkan oleh Culler (1983: 43-63) ditandai dengan jargon "reading as a women" yang diungkapkannya sebagai berikut,

"When we posit a woman reader, the result is an analogous appeal to experience: not to the experience of girlwatching but to the experience of being watched, seen as a "girl", restricted, marginalized."

'Ketika kita menempatkan seorang pembaca perempuan, hasilnya adalah suatu daya tarik yang serupa dengan pengalaman: bukan pengalaman mengamati perempuan, tetapi pengalaman diamati, dipandang sebagai "perempuan", dibatasi, terpinggirkan.'

Dari pendapat Culler tersebut dapat dimengerti bahwa "reading as a women" merupakan usaha sadar para perem-puan untuk mengubah tirani ando-sentris yang male oriented dan cende-rung memengaruhi pembaca perem-puan untuk mengidentifikasikannya dengan tokoh laki-laki. Cara kerja kritik sastra feminis menurut Winata (1988:1) merangkum berbagai pendekatan yang ada seperti sosiologi sastra, resepsi, strukturalisme, tekstual, semiotik, psikologi, sosiologi, antropologi, dan sebagainya.

Kritik sastra feminis pada dasarnya merupakan suatu kritik yang memandang sastra dengan kesadaran khusus akan adanya jenis kelamin tertentu yang memengaruhi politik, sosial, ekonomi, budaya, dan sastra. Menurut Ruthven (1984:24-58) kajian kritik sastra feminis meliputi tiga hal berikut:

1. Kajian perempuan tentang pandangan laki-laki terhadap perempuan dan bagaimana dunia perempuan digambarkan.

2. Kajian tentang kreativitas perempuan yang bersangkutan dengan 
potensinya di tengah tradisi kekuasaan laki-laki.

3. Kajian yang berkaitan dengan penggunaan teori dalam penelitian mengenai perempuan.

Millet dalam Culler (1983: 47) mengungkapkan bahwa sasaran kritik sastra feminis adalah memberikan respon kritis terhadap pandanganpandangan yang terwujud dalam karya sastra yang tampak pada penggambaran budayanya yang berlanjut dengan pertanyaan hubungan antara teks, kekuasaan, dan seksualitas yang terungkap di dalam teks.

Oleh karena itu, penelitian terhadap Garis Perempuan berkaitan dengan isu perempuan yang meliputi permasalahan kesejahteraan, kebebasan pribadi, dan keadilan sosial yang dianalisis melalui keempat tokoh sentral yang berpusat pada bagaimana masing-masing keempat tokoh perempuan memaknai virginitas dalam hidupnya. Untuk memudahkan analisis, maka penelitian dimulai dari sudut pandang pencerita dalam menyajikan bagaimana perempuan dihadirkan. Hal tersebut menyangkut masalah persepsi atau apa yang Luxemburg (1989: 119156) sebagai fokalisator. Selaku pengarang, Kuncoro cenderung mengandalkan fokalisator di luar cerita (orang ketiga) meskipun fakta teks menunjukkan adanya pergeseran fokalisasi berupa keempat tokoh perempuan sebagai fokalisator, namun sifatnya minor saja.

Pada saat cerita pertama Garis Perempuan dibuka, pembaca berhadapan dengan "sosok" di luar cerita sebagai fokalisator ekstern. Pada tahap fokalisasi akhir, pembaca juga berhadapan dengan fokalisator ekstern yang menutup ceritanya setelah keempat tokoh perempuan menjalani serangkaian konflik melalui fokalisasinya masing-masing serta memberikan penilaian terhadap pengalaman hidup keempat tokoh tersebut. Pentingnya penganalisisan mengenai bagaimana perempuan dihadirkan berfokus pada isu-isu perempuan yang dihadirkan, hubungan antara tokoh perempuan dan laki-laki untuk melihat gender role yang bermain di dalamnya.

Djajanegara (2003: 4) mengungkapkan bahwa inti tujuan feminisme adalah meningkatkan kedudukan dan derajat perempuan agar sama atau sejajar dengan kedudukan serta derajat laki-laki. Menghadapi realitas yang selalu bias, sastra hadir berperan menyuarakan. Karenanya, kritik sastra feminis muncul sebagai kacamata feminis dengan motif untuk mendapatkan hak yang sama guna mengungkapkan makna-makna baru yang berbeda dari teks-teks lama. Kritik sastra feminis bekerja dengan membaca, menafsirkan, dan menilai teks yang relevan baginya. Kritik sastra feminis menekankan pemahaman pada oposisi yang terbangun antara laki-laki dan perempuan serta memaknai bagaimana posisi dan peran perempuan yang dihadirkan dalam teks guna mengungkapkan lebih jauh kesetaraan yang terbangun antara tokohtokoh di dalamnya.

Berbekal objek dan konsep teori kritik sastra feminis, penelitian ini membutuhkan metode berupa analisis kajian pustaka yang bersifat kualitatif. Penelitian ini bermaksud memahami fenomena apa yang dialami oleh objek penelitian secara holistik (utuh) dan dengan cara deskripsi dalam bentuk kata-kata dan bahasa, pada suatu konteks khusus yang alamiah dan dengan memanfaatkan berbagai metode alamiah (Moleong, 2007: 6). 
Penerapan kritik sastra feminis terhadap suatu karya dimulai dari analisis terhadap tokoh-tokoh utama dan tokoh sampingan. Djajanegara (2003) dalam bukunya Kritik Sastra Feminis menyatakan bahwa pengidentifikasian tokoh utama merupakan langkah awal dalam penerapan kritik sastra feminis. Pada Garis Perempuan, analisis tokoh meliputi penganalisisan karakter sentral dan perannya dalam mendobrak hukum patriarki, khususnya yang berkaitan dengan virginitas. Tokoh yang akan dianalisis dalam novel ini adalah keempat tokoh sentral perempuan, yakni tokoh Ranting, Gendhing, Tawangsri, dan Zhang Mey.

\section{Pembahasan}

\subsection{Ranting : Seksualitas sebagai Upaya Pengentasan Kemiskinan}

Jalan cerita tokoh ini berputar sekitar Ranting dan pernikahannya dengan Basudewo. Diceritakan bahwa hidup sebagai anak yatim yang ibunya terkena penyakit tumor ganas, Ranting remaja harus putus sekolah dan berjualan karak yang merupakan pemasukan satusatunya. Sebagai perempuan yang tengah berada pada himpitan ekonomi, Ranting merupakan "Dahan yang patah tak berdaya dari pohon penumbuhnya, lalu mengering sia-sia" (Kuncoro, 2010: 35). Ia digambarkan sebagai sosok perempuan yang ringkih oleh segala keterbatasan namun tetap harus berjuang karena keadaan. Hingga pada akhirnya Basudewo, seorang laki-laki dengan tiga istri, datang dengan bantuannya yang menggiurkan yakni berupa pelunasan biaya rumah sakit sekaligus pemberian rumah yang layak huni yang kesemuanya itu tidaklah gratis,

"Maksudku, Mbok War mungkin bisa membuatnya mengerti bahwa tidak semua perempuan harus menjadi istri pertama. Bahwa di zaman dahulu atau sekarang, lumrah terjadi seorang laki-laki memiliki istri lebih dari satu, selama dia sanggup memenuhi kaidah hukum dan agama yang berlaku. Bahwa bagi perempuan menjadi istri pertama, kedua, atau ketiga, cenderung sama saja, tak terlalu jauh perbedaanya," (Kuncoro, 2010: 62).

Berdasarkan pernyataan tersebut, dapat diketahui bahwa pemikiran Basudewo begitu patriarkis yang dapat dilihat dari pernyataannya yang mengatakan bahwa "di zaman dahulu atau sekarang, lumrah terjadi seorang laki-laki memiliki istri lebih dari satu" dan "Bahwa bagi perempuan menjadi istri pertama, kedua, atau ketiga, cenderung sama saja, tak terlalu jauh perbedaannya,". Pernyataan tersebut sarat akan upaya pendominasian laki-laki terhadap perempuan yang telah menjadi sesuatu yang tampak lumrah dan memang seharusnya. Dominasi tersebut mendiskreditkan Ranting sebagai perempuan yang seharusnya mendapatkan hak hidup dan kesempatan yang sama untuk meraih kesejahteraan.

Dari apa yang telah dikatakan Basudewo ini, secara tidak langsung telah mengisyaratkan bahwa dia membutuhkan Ranting sebagai media timbal balik atas bantuannya tanpa memikirkan hak-hak Ranting sebagai manusia. Tindakan Basudewo tersebut jelas merendahkan derajat kaum perempuan dengan tidak mengindahkan posisi perempuan sebagai pasangan hidup. Dengan harga diri yang dimiliki oleh Ranting, dia dan Simbok pada awalnya berusaha bertahan dengan tidak menerima tawaran Basudewo. 
Namun, pada akhirnya demi menyelamatkan nyawa sang Ibu, Ranting terpaksa menikahi Basudewo. Dalam melakoni kewajiban sebagi istri, dua kali seminggu Ranting harus melayani nafsu Basudewo. Merasa hidup dalam mahligai rumah tangga yang tidak bahagia, Ranting tidak ingin menjadi istri Basudewo selamanya. Sejatinya, kegiatan seksualitas haruslah diimbangi oleh perasaan cinta, seperti yang dikatakan oleh Setyawan (2004:87) bahwa,

"Cinta dapat menjadi pendorong pada hubungan seksual. Tapi, bisa jadi hubungan seksual tidak disertai cinta. Artinya, hubungan seksual itu bukan ungkapan cinta. Kalau begitu, tentulah tidak ada kebahagiaan, karena yang terjadi adalah hubungan seksual atas dasar insting seksual yang direduksi sebagai epithymia belaka. Hubungan seksual hanya mungkin membahagiakan kalau dilandasi oleh cinta seksual (eros) dan bukannya insting seksual (epithymia)."

Berdasarkan pemahaman tersebut, tampaklah bahwa Ranting sama sekali tidak mendapatkan kebahagiaan dari pernikahannya bersama Basudewo. Karena dirasa hidup dalam mahligai rumah tangga tanpa rasa cinta, Ranting bersiasat untuk menjual dirinya kepada Basudewo dengan harga dua ratus lima puluh ribu tiap persenggamaan, "Akan kuhitung setiap kali dia datang dan melakukannya. Akan kucatat tanggal kedatangannya, sebagai bukti dan data pendukung pada akhir perhitungan nanti." (Kuncoro, 2010: 99). Ranting menjadikan kegiatan seksual menjadi ladang penghasilan yang mampu membebaskan dirinya dari jeratan pernikahan.

Siasat yang tengah dilakukan Ranting untuk keluar dari dekapan
Basudewo sejalan dengan konsep feminis yang mengupayakan pembebasan kaum perempuan dari segala jenis bentuk penindasan. Kemandirian berpikir bahkan segala upaya dalam memperjuangkan kesetaraan menjadi konsep yang diusung oleh kaum feminis. Keputusan yang diambil oleh Ranting kembali menguatkan perannya sebagi perempuan yang mencoba tetap bereksistensi dalam sistem budaya patriarki. Namun, kebimbangan untuk menegaskan langkah didapati Ranting ketika Basudewo yang berdasarkan pernyataannya tulus meminangnya sebagai istri,

"Bahwa selama ini kau merasa kuperkosa. Tindakan pemerkosaan bisa dituntut dengan UU Kekerasan dalam Rumah Tangga, entah pasal berapa. Aku melakukannya 99 kali, berulang-ulang. Jadi, hukuman apa yang akan divoniskan kepadaku? Tapi, kau menanggungnya sendirian, tanpa punya kemampuan untuk menuntutku karena kau terjebak dalam ikatan perkawinan dengan$\mathrm{ku}$, pemerkosamu. Itu yang tak akan terbayar olehku, berapa pun harta yang kuberikan kepadamu sebagai penukarnya." (Kuncoro, 2010: 117)

Pernyataan di luar dugaan tersebut keluar dari Basudewo yang dengan sengaja memperistri Ranting yang jelas tidak mencintainya. Hal tersebut begitu kontradiktif mengingat kepribadian Basudewo sendiri yang memandang rendah perempuan dengan menikahi tiga orang perempuan sekaligus. Pernyataan terakhir yang dilontarkan Basudewo tersebut pada akhirnya memberikan kebimbangan pada Ranting dan cerita dibiarkan terbuka tanpa adanya putusan tegas dari Ranting sendiri untuk tetap melanjutkan gugatan cerainya ataupun tetap menjadi istri Basudewo. 
Dalam kisah hidup Ranting yang perlu diperhatikan adalah upayanya untuk keluar dari jeratan pernikahan karena tidak adanya kebahagiaan yang ia dapatkan dari sebuah hubungan pernikahan. Demikian halnya dengan virginitasnya. Ranting menyerahkan virginitasnya kepada Basudewo yang berorientasi pada pelunasan hutanghutangnya. Hal tersebut menunjukkan bahwa virginitas yang dimiliki seorang Ranting difungsikannya sebagai solusi atas krisis ekonomi yang menjeratnya. Ia tidak lagi mempedulikan stigma perempuan murahan atau pelacur yang bisa saja ditujukan Basudewo kepadanya. Stigma negatif tersebut tidak penting lagi karena yang terpenting adalah Ranting mampu melunasi hutang-hutangnya sekaligus keluar dari jeratan pernikahan yang tidak membahagiakan.

Berdasarkan pemaparan tersebut maka dapat diketahui bahwa secara tidak langsung Ranting telah memiliki upaya dalam menuntut adanya kesetaraan antara hak perempuan dan laki-laki. Meski tumbuh dalam adat Jawa yang kental, Ranting memiliki ketegasan hati dalam menentukan arah hidupnya. Ia tidak lagi tunduk dalam stereotipe perempuan dalam budaya patriarki, melainkan sosok yang dapat menegosiasikan tekanan dari budaya patriarki untuk memperoleh kebahagiaan lahir dan batinnya.

\subsection{Gendhing : Keutuhan Martabat Perempuan dalam Virginitas}

Serupa dengan Ranting, tokoh Gendhing dihadirkan sebagai perempuan dengan permasalahan ekonomi yang tengah bertahan di kerasnya kehidupan. Ia merupakan perempuan remaja yang ingin masuk di perguruan tinggi setelah tamat SMA. Namun, himpitan ekonomi tak lantas membuatnya menyerah,

"Walau begitu, tidak berarti aku tidak layak untuk miliki cara berpikir yang setara dengan mereka. Aku juga berhak untuk merancang masa depanku, yang barangkali sama dan sebangun dengan rancangan mereka. Dengan atau tanpa pendidikan tinggi, akan kuperoleh jalanku sendiri untuk mendapatkan masa depan itu." (Kuncoro, 2010: 167).

Karena tak mampu melanjutkan ke jenjang perguruan tinggi, Gendhing memilih untuk meringankan beban orang tuanya, yakni bekerja. Ia bekerja di salon milik majikan ibunya. Ia menjadi kapster salon dan disitulah ia bertemu dengan Pak Indragiri, lelaki congkruen paruh baya yang sudah beristri.

Pak Indragiri, layaknya Pak Basudewo dalam kisah hidup Ranting. Ia merupakan secercah harapan bagi kehidupan Gendhing yang kala itu mengalami permasalahan finansial. Ibu Gendhing tertipu oleh sebuah lembaga koperasi. Padahal, simpanan ibu Gendhing yang disimpan sebesar dua puluh juta adalah uang pinjamannya kepada rentenir. Merasa tidak ada jalan lain, Gendhing berniat menjual keperawanannya kepada Pak Indragiri untuk menutup hutang ibunya,

"Aku tidak akan menjadikan diriku sebagai perempuan lain bagi seorang laki-laki, dengan atau tidak berdasarkan perkawinan yang sah. Yang kulakukan ini adalah transaksi. Cukup satu kali kulakukan, dia ambil perawanku, kuterima uangnya, lalu selesai." (Kuncoro, 2010: 196).

Saat Gendhing dan Pak Indragiri memulainya, tiba-tiba Gendhing ber- 
ubah pikiran. Ia teringat akan kedua orang tuanya dan kasih sayang yang membanjiri hidupnya. Keinginan Gendhing untuk menjual keperawanannya diyakini hanya sebagai antusiasme pencarian solusi belaka atas tragedi yang menimpa keluarganya. Ia merasa sebagai perempuan, hal yang ada pada dirinya tak akan pernah dirasa cukup dinilai dari segi materi.

"Aku hanya tergoda imajinasi palsu yang kau tawarkan. Tapi, aku belum kalah, tetap kumiliki diriku dengan utuh. Tak akan aku menyerah pada jamaahanmu atau takdir. Kalaupun aku harus tetap miskin, akan tetap kujaga nilai diriku sebagai yang utama." (Kuncoro, 2010: 210).

Keputusan tersebut telah mutlak dipilih Gendhing dan sebagai konsekuensinya ia harus mengalihkan hutang orang tuanya kepada Cik Ming dan menggantinya dengan menjadi kapster tanpa gaji.

Keputusan Gendhing untuk menjual virginitasnya kepada pak Indragiri tampak sebagai upaya untuk keluar dari problematika ekonomi yang serupa dengan apa yang dilakukan oleh tokoh Ranting. Namun, perbedaan tampak pada aksi dari keduanya. Apabila Ranting rela menikah dengan Basudewo dalam rangka melunasi hutanghutangnya, Gendhing tampak begitu menghargai virginitas yang tidak bisa dilepaskan dari hubungan kasih sayang yang terjalin antara anak dan orang tua. Gendhing menganggap bahwa dengan memperlakukan virginitasnya secara tidak hormat, sama saja dengan tidak menghormati dan menghargai usaha kedua orangtuanya dalam merawat dan membesarkannya.

Selain itu, pada dasarnya Gendhing juga tidak memiliki ketertarikan hati kepada Indragiri selain ketertari- kan terhadap materi. Seperti yang telah dijelaskan dalam permasalahan Ranting, cinta dibutuhkan dalam hubungan seksualitas. Hal tersebut pulalah yang mendorong keengganan Gendhing untuk menjual keperawanannya kepada Indragiri. Karena menganggap bahwa keperawanan adalah hal yang tidak hanya sekadar bersifat jasmaniah namun bersifat rohaniah, maka Gendhing dengan anggapan atas dirinya yang utuh menolak untuk menjadikan virginitas sebagai alat transaksi keuangan.

Dari pemaparan tersebut maka dapat diketahui bahwa Gendhing memaknai virginitas sebagai sesuatu yang bertalian erat dengan faktor psikis dan nilai keutuhan diri. Keutuhan diri diyakininya sebagai sesuatu yang harus diperjuangkan dalam hidup seperti yang tampak dari perjuangan kedua orangtuanya dalam membesarkannya. Pendirian yang dimiliki oleh Gendhing sejalan dengan gerakan feminis bahwa manusia memiliki harganya sendiri yang tak dapat disandingkan dengan materi.

\subsection{Tawangsri: Garis yang Menyim- pang dari Jalur Patriarkat}

Tawangsri merupakan sosok yang mendambakan figur seorang ayah. Dalam kekeringan kasih sayang sang ayah, hatinya jatuh pada seorang lakilaki paruh baya yang dilihatnya di taman kota. Laki-laki itu adalah Jenggala, seorang duda yang istrinya meninggal saat melahirkan anaknya, Langit. Diawali dari kesamaan profesi sebagai akademisi yang fokus pada kajian gender, Tawangsri memiliki keter-tarikan terhadap Jenggala yang secara diam-diam juga memiliki rasa yang sama. Tawangsri menilai bahwa Jenggala bukanlah lelaki patriarkis. Jenggala menaruh penghormatan yang 
tinggi terhadap perempuan yang tampak melalui argumentasinya,

"Kadang-kadang dunia memang terasa sangat patriarkat. Ada keterbelahan yang tajam pada kedudukan perempuan saat ini. Sebagian perempuan menempati posisi baik di ruang publik, sementara banyak perempuan lainnya, menjalani hidup tanpa pilihan lain selain menjadi ibu dan sarana rekreasi seksual para suami." (Kuncoro, 2010: 255)

Pandangan hidup Jenggala yang sedemikian rupa menjadi data narasumber tepat yang dibutuhkan Tawangsri yang kala itu tengah mengerjakan tugas perkuliahan. Serupa aliran air yang pasti menuju lautan, Tawangsri bermuara pada keputusannya untuk memberikan keperawanannya pada Jenggala.

“Akan kupergunakan hak pilihku untuk menentukan siapa laki-laki pertamaku. Sama seperti seorang laki-laki memilih perempuan pertamanya. Tidak ada keharusan bagiku untuk tetap menjadi perawan demi sebuah pernikahan. Menjadi tetap perawan atau tidak adalah suatu pilihan dan aku hanya akan melakukannya dengan seseorang yang kuinginkan, dengan atau tanpa pernikahan." (Kuncoro, 2010: 274).

Di tengah persetubuhannya dengan Jenggala, tiba-tiba Tawangsri merasakan kehadiran Langit yang mencari ayahnya. Tiba-tiba saja tangisan Langit yang sedang mencari sosok ayahnya merupakan refleksi tangisannya yang juga mencari sosok sang ayah. Dengan hadirnya kepiluan yang mendalam, Tawangsri menghentikan itu dan ia berniat mengakhiri hubungan dengan Jenggala setelah ini semua selesai.
Tawangsri menyudahi hubungannya dengan Jenggala karena ia merasa bahwa Jenggala hanyalah lelaki patah hati yang kesepian dan selalu menyimpan ruang untuk mendiang istrinya. Meski keperawanannya terenggut, Tawangsri tidak berharap agar Jenggala bertanggung jawab. "Ketahuilah, dengan apa yang telah kita lakukan ini, bagiku tidak ada yang harus ditanggung dan tidak ada pertanyaan yang harus dijawab. Aku tidak sedang melakukan barter keperawananku sebagai upaya untuk mendapatkanmu. Aku bukan pula perempuan moralis yang menjauhkan diri dari hasrat erotisku demi penjagaan sebuah citra." (Kuncoro, 2010: 283).

Tawangsri melalui pernyataan tersebut menolak untuk menjaga suatu citra yang dibangun secara patriarkis yang menurut Syahrul (2013:40) merupakan gambaran yang harus ada pada perempuan Indonesia pada saat ini. Keputusan Tawangsri tersebut secara tidak langsung telah meneguhkan dirinya sebagai manusia yang memiliki kebebasan dalam menentukan laku hidupnya termasuk dalam memperlakukan virginitas. Keperawanan dimaknainya sebagai sesuatu yang hanya pantas dimiliki oleh orang pilihannya. Meskipun orang pilihan tersebut tidak akan hidup bersamanya, hal tersebut bukan menjadi masalah karena esensi dari hubungan seksualitas yang pertama kali dilakukan seorang perempuan terletak pada adanya ketertarikan dari masing-masing pihak yang dilandasi rasa cinta.

Pilihan hidup yang diambil Tawangsri tidak dapat dilepaskan dari studinya terhadap kajian gender. Meski dibesarkan oleh ibu yang sangat 
menaati partitur perkawinan, Tawangsri merupakan perempuan yang menjauhi "garis batasnya", yang dibangun sesuai dengan stereotipe budaya patriarki. Ia menjauhi konstruksi patriarki yang menempatkan perempuan di bawah kuasa laki-laki. Pada dasarnya yang berkuasa terhadap tubuh Tawangsri hanyalah dirinya sendiri dan hal tersebut sesuai dengan pendapat Prabasmoro (2007: 31) yang mengatakan bahwa bagaimanapun seorang perempuan adalah pertamatama seorang manusia. Tubuhnya tidak seharusnya dipandang sebagai penjara dan keterbatasan, melainkan suatu "cengkeraman", suatu sentuhan, terhadap dunia.

\subsection{Zhang Mey : Subjektivitas Perempuan dalam Seksualitas}

Tokoh Zhang Mey berlatar belakang budaya dan adat Tionghoa di Indonesia. Zhang Mey tumbuh dalam konsep virginitas yang diyakini sebagai bentuk anugerah Tuhan terhadap perempuan yaitu adanya selaput hymen (selaput dara tipis) yang harus dijaga hingga hari pernikahan tiba. Hymen tersebut hanya boleh sobek di malam pertama suatu pernikahan dan stigma buruk akan melekat kepada perempuan apabila selaput tersebut telah sobek sebelum malam pertama. Dikisahkan bahwa ibu Zhang Mey merupakan sosok perempuan yang menjaga tatanan patriarki tersebut. Hal tersebut tampak saat ia berpesan pada Zhang Mey,

"Hanya satu kali kau menjadi perawan, harus kau jaga yang satu itu dengan sungguh sampai saatnya tiba.

Saat kau menikah nanti, ibu mertuamu akan menyiapkan saputangan putih untuk menampung darah perawanmu. Harus bisa kau buktikan bahwa itu darah pertamamu." (Kuncoro, 2010: 296).

Pesan ibu Zhang Mey tersebut menyiratkan bahwa seorang perempuan merupakan sosok yang harus berjuang untuk menunjukkan eksistensinya dalam aturan main yang dibentuk oleh budaya dan tradisi yang begitu patriarkis. Adat Tionghoa dalam novel ini menekankan pada pentingnya pembuktian atas sobeknya selaput hymen yang akan menjadi patokan dalam menilai kualitas seorang perempuan. Di lain sisi, laki-laki yang tidak dianugerahi selaput hymen secara praktis terbebas dari penilaian kualitas seseorang yang didasarkan dari kondisi fisik tubuh tersebut. Ketidakadilan dalam menilai kualitas laki-laki dan perempuan tersebut merupakan keyakinan yang dipertahankan oleh Ibu Zhang Mey yang pada akhirnya menimbulkan problematika tersendiri yang menimpa anaknya.

Titik krisis dalam hidup Zhang Mey terjadi ketika ia jatuh cinta kepada seorang laki-laki dengan latar budaya Jawa yang bernama Tenggar. Perbedaan etnis, budaya, dan tradisi membuat Zhang Mey patah arang dalam memperjuangkan cintanya. Terdesak oleh cinta yang menggebu dan pelampiasan atas ketidakberdayaannya terhadap hukum adat budaya Tionghoa, Zhang Mey berniat menyerahkan keperawanannya kepada Tenggar sebagai aksi pemberontakan.

Ketika tiba hari Zhang Mey hendak menyerahkan keperawanannya kepada Tenggar, dengan tiba-tiba Tenggar menolak Zhang Mey. Tenggar menganggap bahwa apa yang dilakukan pacarnya kepadanya tersebut merupakan sesuatu yang dapat menghancurkan diri Zhang Mey sendiri, 
"Perempuan lebih mempunyai kemampuan kuat untuk bertahan, sementara aku laki-laki sangat lemah dalam pertahanan semacam ini. Tidak ada laki-laki mana pun yang memiliki kekuatan setangguh perempuan dalam mendindingi diri dari jangkauan berahi. Maka, janganlah menyerah karena bila kau menyerah, apalagi aku? Sungguh aku tak akan mampu menjagamu, justru dari diriku sendiri. Kumohon, bertahan-lah..." (Kuncoro, 2010: 348).

Pernyataan Tenggar tersebut merupakan pernyataan yang keluar dari konstruksi budaya patriarki. Hal tersebut tampak dari perkataannya yang menekankan pada perbedaan jenis kelamin "laki-laki" dan "perempuan". Ia menganggap Zhang Mey sebagai objek yang menghadirkan tanggung jawab moril yang tampak sebagai keharusan perlakuan kepada perempuan. Konsep tanggung jawab tersebut mengisyaratkan bahwa ia sebagai lakilaki adalah "pelindung" dan perempuan adalah sosok yang harus "dilindungi" atau dengan kata lain ia tengah berusaha menunjukkan dominansi kekuatannya. Dominansi kekuatan ini seperti mengatakan "Aku bebas berbuat apa saja padamu. Aku tidak peduli walaupun itu bisa mengganggumu dan kamu juga tidak akan bisa berbuat apa-apa". Perlindungan yang seharusnya diberikan kepada perempuan memberikan ruang kepada perempuan untuk berpikir bahwa dirinya hanyalah sebuah objek dan lakilaki sebagai subjek. Hal tersebut dijelaskan oleh Prabasmoro (2007:83) yang mengungkapkan bahwa konsep patriarki menempatkan laki-laki sebagai subjek dan perempuan lebih banyak dituntut sebagai objek sehingga perempuan memiliki fungsi periferal yang secara keseluruhan berpusat pada laki-laki.

Penolakan Tenggar terhadap Zhang Mey membuatnya kehilangan kesempatan untuk menunjukkan eksistensi dan rasa cintanya kepada Tenggar. Tidak hanya pada tokoh Tenggar, secara keseluruhan, akhir cerita masingmasing tokoh pada novel ini harus berakhir pada kejayaan konstruksi patriarkis di Indonesia yang menekan perempuan untuk dapat menunjukkan eksistensinya sebagai seorang manusia yang memiliki hak dan kesempatan hidup yang sama dengan laki-laki.

\section{Simpulan}

Novel Garis Perempuan mengisahkan tentang keempat sahabat yang harus menjalani takdir kehidupan sebagai perempuan. Masing-masing tokoh memiliki keputusan sendiri terkait dengan virginitas yang dimilikinya. Tokoh Ranting memaknai virginitas sebagai alat tukar yang mampu membebaskan dirinya dari jeratan ekonomi. Hal tersebut tidak jauh berbeda dengan tokoh Gendhing yang berniat menjual keperawanannya kepada Indragiri guna menutup hutang ibunya, namun urung mengingat jasa kedua orang tuanya yang telah menjaganya yang dianggapnya tak sepadan dengan pilihan menjual keperawanannya. Lain halnya dengan tokoh Tawangsri. Ia hanya akan melepaskan keperawanannya dengan laki-laki pilihannya atau dengan lakilaki yang dicintainya. Tidak menjadi masalah apakah ia akan terus bersama atau berpisah dengan laki-laki tersebut karena makna keperawanan adalah ketulusan untuk menyerahkan sesuatu yang paling berharga dalam hidupnya untuk orang yang dicintainya. Zhang Mey berniat untuk menyerahkan keperawanannya kepada Tenggar sebagai 
pemberontakan terhadap sistem nilai pada budaya Tionghoa. Namun, hal tersebut urung dilakukan karena Tenggar yang berpandangan patriarkis menganggap Zhang Mey hanya akan menyengsarakan dirinya sendiri karena perbuatan yang dilakukannya.

Dalam teks ini dapat diketahui bahwa tokoh Ranting menempatkan virginitas sebagai area yang mampu dipertukarkan dengan materi. Ia berada dalam permasalahan finansial sehingga memanfaatkan virginitas sebagai jalan keluar. Meskipun hampir memiliki pemahaman yang serupa, Gendhing menolak untuk menjadikan virginitas sebagai alat tukar uang. Virginitas dianggapnya sebagai sesuatu yang sakral dan pantas untuk dijaga. Lain halnya dengan Tawangsri dan Zhang Mey. Tawangsri dan Zhang Mey yang tidak memiliki masalah finansial, menempatkan virginitas sebagai bukti tanda cinta. Keduanya rela melepaskan virginitas kepada seseorang yang dipilihnya atas dasar cinta semata.

Teks Garis Perempuan melukiskan wujud permasalahan perempuan: cinta dengan perbedaan sosiokultural, pembagian kerja secara seksual, dan virginitas dalam budaya patriarki. Tokoh Ranting, mengalami permasalahan yang lebih dari tokoh-tokoh perempuan lainnya karena tokoh ini mengalami perbenturan dan pergeseran nilai dalam hidupnya akibat kemiskinan yang mau tak mau telah mengorbankan dirinya untuk mendapatkan kebebasan sebagai manusia yang bebas, utuh, dan memiliki nilai diri. Meskipun demikian, di tengah kultur patriarki yang sedemikian rupa, Ranting mampu bertahan dalam hidupnya dengan kecerdasan emosional yang dimilikinya. Berawal dari pernikahan paksa yang dilakukannya untuk ter- lepas dari lilitan hutang, kehidupan Ranting yang diliputi kesedihan berangsur membaik karena ia mampu mengelola strategi untuk kembali mencapai kebebasannya.

Sesuai dengan teori kritik sastra feminis yang merupakan alat analisis acuan dalam tulisan ini, keempat tokoh perempuan dalam Garis Perempuan sama-sama memiliki permasalahan dalam kesejahteraan, kebebasan pribadi, dan keadilan sosial. Meskipun para tokoh telah mengupayakan kesejahteraan, kebebasan, dan keadilan, namun hal tersebut tampak sebagai impian yang sia-sia yang tampak dari akhir cerita masing-masing tokoh: (1) Ranting, bimbang untuk memutuskan berpisah dengan Basudewo yang telah merampas kebahagiaannya; (2) Gendhing, menjadi kapster tanpa bayaran demi melunasi hutang ibunya; (3) Tawangsri dan (4) Zhang Mey, berpisah dengan orang yang dicintainya karena terbentur norma, adat, dan budaya. Keempat tokoh tersebut pada akhirnya harus kalah dalam melawan budaya patriarki yang telah di"garis"kan oleh kaum patriarkis di Indonesia, yang sesuai dengan judul novel karya Kuncoro ini, Garis Perempuan.

Pada akhirnya dapat diketahui bahwa novel Garis Perempuan tidak dapat dilepaskan dari kekuasaan dan seksualitas di dalamnya. Melalui keempat tokoh sentral tersebut, dapat dipahami bahwa Garis Perempuan mencirikan perjuangan kaum perempuan di Indonesia untuk meraih kesejahteraan, kebebasan pribadi, dan keadilan sosial melalui konsep virginitas yang memiliki pemaknaan berbeda oleh masing-masing pemiliknya. Meskipun berlatar dari budaya dan tradisi yang menjunjung tinggi sistem patriarki, perempuan dalam novel ini 
menempatkan virginitas di bawah kuasanya sehingga secara tidak langsung telah tampak upaya pencapaian kesejahteraan yang diupayakan oleh masing-masing tokoh. Namun, sekeras apapun perjuangan masing-masing tokoh perempuan dalam mengupayakan kesetaraan dan menunjukkan eksistensinya di mata publik, kesejahteraan, kebebasan pribadi, dan keadilan sosial menjadi sesuatu yang mustahil diraih di negara dengan sistem patriarki yang telah mendarah daging. Di balik kerasnya hukum dan budaya patriarki, alih-alih moral yang harus ditaati, seorang perempuan pada dasarnya mampu menjadikan virginitas sebagai sesuatu yang bermanfaat bagi dirinya secara pribadi.

\section{Daftar Pustaka}

Astutiningsih, Irana. (2013). "Laki-laki Cantik di Mata Perempuan: Konstruksi Tubuh Superhero dalam Sastra Cyber". Jurnal Jentera, 2 (2), 53-61.

Bill Ashcroft, dkk. (2003). Menelan-jangi Kuasa Bahasa. Yogyakarta: CV. Qalam.

Djajanegara, Soenarjati. (2003). Kritik Sastra Feminis. Jakarta: PT Gramedia Pustaka Utama.

Djajanegara. (1995). Citra Wanita dalam Lima Novel Terbaik Sinclair Lewis dan Gerakan Wanita di Amerika. Depok: Fakultas Sastra Universitas Indonesia.

Fananie, Zainuddin. (2002). Telaah Sastra. Surakarta: Muhammadiyah University Press.
Guamarwati, Nandika Ajeng. (2009). "Suatu Kajian Kriminologis Terhadap Perempuan dalam Relasi Pacaran." Jurnal Kriminologi Indonesia, 5 (2), 65-78.

Jamhari dan Ismatu Ropi. (2003). Citra Perempuan dalam Islam. Jakarta: PT Gramedia Pustaka Utama.

Kuncoro, Sanie B. (2010). Garis Perempuan: Empat Wanita Empat Jalan Hidup. Yogyakarta: PT. Bentang Pustaka.

Kusumawati, Widya Putri. (2014). Aspek Sosial dalam Novel Garis Perempuan Karya Sanie B Kuncoro: Tinjauan Sosiologi Sastra dan Implementasinya sebagai Bahan Ajar di SMA. Skripsi. Surakarta: Fakultas Keguruan dan Ilmu Pendidikan, Universitas Surakarta.

Lilis A, Nenden. (2012). "Pasca-kolonial, Teks dan Gerakan Sastra." Jurnal Cerpen Indonesia, (12), 105-115.

Naeem, Abdul. (2010). Al-Quran ku. Jakarta: Lautan Lestari.

Prabasmoro, Aquarini Priyatna. (2007). Kajian Budaya Feminis: Tubuh, Sastra, dan Budaya Pop. Yogyakarta: Jalasutra.

Ratna, Nyoman Kutha. (2009). Stilistika: Kajian Puitika Bahasa, Sastra, dan Budaya. Yogyakarta: Pustaka Pelajar.

Setyawan, A. 2004. Seks Gadis? Memahami Seks Membuktikan Cinta. Yogyakarta: Galang Press. 
Suwondo, Tirto. (2014) “Kajian Wacana Sastra Pascakolonial dan Pembangunan Karakter Bangsa". Jurnal Jentera, 3 (2), 95-105.

Syahrul, Ninawati. (2013) "Citra Perempuan dalam Kaba Anggun Nan Tungga Karya Ambas Mahkota “. Jurnal Jentera 2 (2), 3952.

Tan, Mely G. (1996). Perempuan Indonesia Pemimpin Masa Depan. Jakarta: Sinar Harapan. 